\title{
MODEL PENINGKATAN KUALITAS AUDIT MELALUI KECERMATAN PROFESIONAL, KOMPETENSI DAN ETIKA AUDITOR INTERNAL DI BPKP PROPINSI RIAU
}

\section{MODEL FOR ENHANCING AUDIT QUALITY THROUGH PROFESSIONAL DISCLOSURE, COMPETENCE AND ETHICS OF INTERNAL AUDITORS IN BPKP RIAU PROVINCE}

\author{
Suharti $^{1}$, Yusrizal ${ }^{2}$ \\ Sekolah Tinggi Ilmu Ekonomi Pelita Indonesia ${ }^{1,2}$ \\ tictuc_aura@yahoo.co.id ${ }^{1}$
}

\begin{abstract}
Audit quality is an inseparable part of good governance that leads to clean government. The purpose of this study was to determine the effect of Professional Accuracy, Competence and Ethics of Internal Auditors on Audit Quality. This research was conducted in BPKP Representatives of Riau Province with an auditor sample of 46 people. Data collection method is to use a questionnaire list. While the method of data analysis using multiple linear regression analysis The results of the study show that Professional Accuracy has no significant effect on Audit Quality, Auditor Quality has a significant effect on Audit Quality. Auditor Ethics has a significant effect on Audit Quality.
\end{abstract}

Keywords: Audit Quality, Professional Accuracy, Competence, Ethics of Internal Auditors

\begin{abstract}
ABSTRAK
Kualitas audit merupakan bagian yang tidak terpisahkan dari good governance yang mengarah pada pemerintahan yang bersih (clean government). Tujuan dari penelitian ini adalah untuk mengetahui pengaruh Kecermatan Profesional, Kompetensi Dan Etika Auditor Internal Terhadap Kualitas Audit. Penelitian ini dilakukan di Perwakilan BPKP Provinsi Riau dengan sampel auditor sebanyak 46 orang. Metode pengumpulan data adalah dengan menggunakan daftar kuesioner. Sedangkan metode analisis data dengan menggunakan analisis regresi linear berganda Hasil penelitian menunjukkan bahwa Kecermatan Profesional tidak berpengaruh signifikan terhadap Kualitas Audit, Kualitas Auditor berpengaruh signifikan terhadap Kualitas Audit Etika Auditor berpengaruh signifikan terhadap Kualitas Audit.
\end{abstract}

Kata Kunci : Kualitas Audit, Kecermatan Profesional, Kompetensi, Etika Auditor Internal

\section{PENDAHULUAN}

Pembangunan yang dilaksanakan oleh Pemerintah akan dapat terlaksana dengan baik dan tidak menyimpang jika memiliki sistem kelola yang baik atau good government governance. Penyelenggaraan kegiatan Pemerintah untuk pembangunan tersebut sangat 
berkaitan dengan anggaran keuangan yang menjadi sumber pembiayaan dalam pelaksanaannya. Menurut Halim dan Kusufi (2012) untuk meminimalkan terjadinya pemerintahan yang menyimpang dan tidak akuntabel diperlukan sistem akuntabilitas publik yang baik. Salah satu fungsi yang harus ada dalam proses akuntabilitas publik adalah fungsi pemeriksaan atau auditing.

Menurut Mabruri dan Winarna (2010), pertanggungjawaban atas penggunaan dana untuk penyelenggaraan pemerintahan seharusnya didukung dengan suatu pengawasan yang cukup andal guna menjamin pendistribusian dana yang merata pada semua sektor publik sehingga efektivitas dan efisiensi penggunaan dana bisa dipertanggungjawabkan.

Kualitas audit merupakan bagian yang tidak terpisahkan dari good governance yang mengarah pada pemerintahan yang bersih (clean government). Hal ini karena kinerja yang dilaksanakan oleh pemerintah pasti akan di periksa melalui mekanisme evaluasi. Yusuf (2014) menyatakan bahwa audit internal mendorong terciptanya sistem pemerintahan yang bersih dan baik, terutama dalam pengelolaan keuangannya. Oleh sebab itu pelaksanaan audit internal tersebut harus dapat menghasilkan kualitas audit yang baik. Untuk dapat memperoleh kualitas audit maka pelaksanaan audit harus dilakukan oleh auditor yang memiliki kecermatan professional dan kompetensi yang mumpuni. Selain itu etika audit harus menjadi dasar auditor dalam bertindak pada saat melaksanakan audit.

Kualitas audit menjadi hal yang sangat penting pada institusi yang melaksanakan audit. Salah satu institusi tersebut adalah Badan Pengawasan Keuangan dan Pembangunan (BPKP). Menurut Peraturan Presiden Republik Indonesia Nomor 192 Tahun 2014 tentang Badan Pengawasan Keuangan dan Pembangunan, yang dimaksud dengan Badan Pengawasan Keuangan dan Pembangunan (BPKP) adalah suatu institusi yang dibuat oleh pemerintah dengan tujuan untuk melakukan pengawasan intern dalam pemerintahan. Keberadaan BPKP sangat berkaitan dengan pelaksanaan audit terhadap instansi pemerintah pusat yang ada di daerah.

Peraturan Presiden Republik Indonesia Nomor 192 Tahun 2014 tentang Badan Pengawasan Keuangan dan Pembangunan disebutkan bahwa tugas yang harus dilaksanakan oleh badan ini adalah melakukan pengawasan intern terhadap akuntabilitas keuangan negara/daerah dan pembangunan nasional meliputi kegiatan yang bersifat lintas sektoral. Selain itu, badan ini juga bertugas untuk melaksanaan audit, reviu, evaluasi, pemantauan, dan kegiatan pengawasan lainnya terhadap perencanaan, pelaksanaan dan pertanggungjawaban akuntabilitas penerimaan negara/daerah dan akuntabilitas pengeluaran keuangan negara/daerah.

Kualitas Audit sangat dipengaruhi oleh kecermatan professional dan kompetensi auditor, serta pelaksanaan audit tersebut harus berlandaskan pada kode etik audit yang sudah ditentukan. Hal ini telah dibuktikan dengan penelitian terdahulu yang dilakukan oleh Badjuri (2011) yang membuktikan bahwa baik profesionalisme auditor, kompetensi dan kepatuhan pada kode etik memberikan pengaruh pada kualitas hasil pemeriksaan. Hal ini diperkuat dengan penelitian lainnya yang dilaksanakan oleh Jelic (2012) yang membuktikan bahwa kompetensi dan 
etika auditor berpengaruh pada kualitas audit.

Berdasarkan Standar Profesional Akuntan Publik (SPAP) audit yang dilaksanakan auditor dikatakan berkualitas, jika memenuhi ketentuan atau standar pengauditan. Standar pengauditan mencakup mutu professional, auditor independen, pertimbangan (judgement) yang digunakan dalam pelaksanaan audit dan penyusunan laporan audit.

DeAngelo (1981) mendefinisikan kualitas audit sebagai berikut;"the quality of audit services is defined to be the market-assessed joint probability that a given auditor will both (a) discover a breach in the client's accounting system, and (b) report the breach.

Sementara menurut Sutton (1993) dalam Sulaiman dkk (2013) pengertian kualitas audit dapat diartikan sebagai berikut: Audit quality have defined as a process measures that are related to auditor performance (such as audit procedures, judgment and decisionmaking, and quality-threatening behavior).

Kualitas audit merupakan audit yang dilakukan secara independen berdasarkan standar audit APIP dan ketika menemukan penyimpangan dilaporkan secara objektif atas prioritas audit yang telah ditentukan. Dan atas penyimpangan tersebut diberikan rekomendasi yang sesuai dengan penyimpangan dalam LHP kemudian dapat ditindaklanjuti audit (Pohan, 2014).

Berdasarkan pengertian kualitas audit di atas dapat disimpulkan bahwa kualitas audit merupakan segala kemungkinan dimana auditor pada saat mengaudit laporan keuangan klien dapat menemukan pelanggaran yang terjadi dalam sistem akuntansi klien dan melaporkannya dalam laporan hasil audit, dimana dalam melaksanakan tugasnya tersebut auditor berpedoman pada standar audit dan kode etik akuntan publik yang relevan.

Tingginya kualitas hasil audit ditentukan oleh dua bagian (Kovinna dan Betri, 2014) yaitu:

1. Kesesuaian Pemeriksaan dengan Standar Audit. Kualitas audit bisa dihubungkan dengan kesesuaian pemeriksaan dengan standar audit. Standar audit merupakan panduan umum bagi auditor dalam memenuhi tanggung jawab profesinya untuk melakukan audit. Standar audit juga berguna untuk memberikan suatu kerangka kerja dalam menyusun interpretasiinterpretasi. Bagian dari standar audit meliputi: standar umum, standar pekerjaan lapangan, dan standar pelaporan.

2. Kualitas Laporan Hasil Audit. Hal yang penting dalam pelaksanaan audit adalah bagaimana auditor mengkomunikasikan hasil audit dalam bentuk laporan kepada semua pemakai laporan. Laporan audit akan memuat temuan dan simpulan audit yang diberikan beserta rekomendasi kepada para pihak berkepentingan. Laporan audit mengungkapkan informasi terkait laporan keuangan yang ada pada perusahaan/entitas yang diaudit.

Kecermatan professional auditor adalah keadaan dimana auditor harus menggunakan kemahiran profesionalnya dengan cermat dan seksama (due professional care) dan secara hati-hati (prudent) dalam setiap penugasan audit intern (AAIPI, 2014).

Menurut Standar Audit Intern Pemerintah Indonesia (AAIPI, 2014) auditor harus merencanakan dan melaksanakan pekerjaannya dengan menggunakan kemahiran 
profesionalnya secara cermat dan seksama (due professional care) dan secara hati-hati (prudent). Penggunaan kecermatan profesional menekankan tanggung jawab setiap Auditor untuk memperhatikan Standar Audit serta mempertimbangkan penggunaan audit berbasis teknologi dan teknik analisis data lainnya.

Sedangkan menurut Tita, dkk., (2012) auditor yang memiliki sikap profesionalisme yang baik dan tinggi akan menyajikan hasil pemeriksaan secara lengkap, memadai dan sesuai dengan standar yang berlaku. Selain itu, menurut Peraturan Badan Pemeriksa Keuangan Republik Indonesia Nomor 2 Tahun 2011 tentang Kode Etik Badan Pemeriksa Keuangan pasal 1 menyebutkan bahwaprofesionalisme adalah kemampuan, keahlian, dan komitmen profesi dalam menjalankan tugas.

Di dalam Standar Audit Intern Pemerintah Indonesia (AAIPI: 2014) disebutkan bahwa kompetensi auditor adalah dimana seorang auditor harus mempunyai pendidikan, pengetahuan, keahlian dan keterampilan, pengalaman, serta kompetensi lain yang diperlukan untuk melaksanakan tanggung jawabnya.

Menurut Arens (2003) dalam Yusuf (2014) kompetensi adalah kualitas pribadi yang harus dimiliki oleh seorang auditor yang diperoleh melalui latar belakang pendidikan formal auditing dan akuntansi, pelatihan kerja yang cukup dalam profesi dan akan ditekuninya dan selalu mengikuti pendidikan-pendidikan profesi yang berkelanjutan.

Menurut Reni (2010) dalam Yusuf (2014) menunjukkan bahwa indikator kompetensi untuk auditor terdiri atas :

1. Komponen pengetahuan, merupakan komponen yang penting dalam suatu kompetensi. Komponen ini meliputi pengetahuan terhadap fakta-fakta dan prosedur-prosedur.

2. Memiliki kompetensi lain seperti kemampuan berkomunikasi, kreatifitas, kerja sama dengan orang lain.

3. Keahlian yang menyangkut objek pemeriksaan. Mengamati objek dan membandingkan dengan standar yang berlaku, kemudian menarik kesimpulan dari hasil perbandingan tersebut merupakan inti pekerjaan pemeriksaan.

4. Keahlian yang menyangkut teknik atau cara melakukan pemeriksaan Seorang auditor harus memiliki kemampuan teknik atau cara melakukan pemeriksaan yang memungkinkan seorang auditor memperoleh informasi yang maksimal (kualitas dan kuantitas) tentang objek yang diperiksa dalam waktu yang terbatas.

5. Keahlian dalam menyampaikan hasil pemeriksaan Segala temuan, informasi dan data yang diperoleh dalam melaksanakan pemeriksaan harus disampaiakan seluruhnya kepada kepala pemerintahan dan pihak yang diperiksa. Untuk dapat menyampaikan hasil audit kepada kedua pihak tersebut diperlukan keahlian dan kemahiran berbahasa secara baik, benar, efisien, teliti, dan cermat melalui laporan hasil pemeriksaan (LHP).

Etika dapat didefiniskan sebagai serangkaian prinsip atau nilai moral yang dimiliki oleh setiap orang. Lestari (2012) mengemukakan bahwa etika sebagai seperangkat aturan atau norma atau pedoman yang mengatur perilaku manusia, baik yang harus dilakukan maupun yang harus ditinggalkan yang dianut oleh sekelompok atau segolongan manusia atau masyarakat atau profesi. Menurut Halim (2008:29) 
salah satu faktor yang berpengaruh terhadap kualitas audit adalah ketaatan auditor terhadap kode etik, yang terefleksikan oleh sikap independensi, obyektivitas, integritas dan lain sebagainya.

Penelitian yang dilakukan Lindawati $d k k .(2013)$ tentang pengaruh kecermatan profesional dan pengalaman kerja terhadap kualitas hasil pemeriksaan pada auditor Inspektorat Provinsi Gorontalo. Hasil penelitian ini menunjukkan bahwa kecermatan profesional secara parsial berpengaruh signifikan terhadap kualitas Audit

Marsellia (2012) menunjukkan bahwa kompetensi dan independensi memiliki pengaruh yang signifikan terhadap kualitas audit. Selain itu, penelitian ini juga menemukan bahwa interaksi antara kompetensi dan etika auditor serta interaksi antara independensi dan etika auditor memiliki pengaruh yang signifikan terhadap kualitas audit.

Jelic (2012) membuktikan bahwa pengaruh kompetensi tim audit menjadi penting untuk menilai kualitas hasil audit. Suyono (2012) menunjukkan bahwa independensi, pengalaman dan akuntabilitas secara simultan berpengaruh terhadap kualitas audit; namun secara parsial hanya independensi dan akuntabilitas yang mempengaruhi kualitas audit sedangkan pengalaman tidak berpengaruh terhadap kualitas audit. Faktor yang paling mempengaruhi kualitas audit adalah akuntabilitas.

Samsi, et.al (2013) menunjukkan bahwa variabel pengalaman kerja, independensi, interaksi pengalaman kerja dan kepatuhan etika auditor, dan interaksi independensi dan kepatuhan etika auditor berpengaruh terhadap kualitas hasil pemeriksaan. Sedangkan variabel kompetensi dan interaksi kompetensi dan kepatuhan etika auditor tidak berpengaruh terhadap kualitas hasil pemeriksaan.

Al-Khaddas, dkk (2013) menunjukkan hubungan yang positif dan signifikan antara kualitas audit dan efisiensi audit, reputasi kantor audit, biaya audit, ukuran perusahaan audit, dan kemampuan auditor. Sementara Agusti dan Pertiwi (2013) menunjukkan bahwa variabel Kompetensi, Independensi dan Profesionalisme memiliki pengaruh terhadap kualitas audit.

Kecermatan professional auditor adalah keadaan dimana auditor harus menggunakan kemahiran profesionalnya dengan cermat dan seksama (due professional care) dan secara hati-hati (prudent) dalam setiap penugasan audit intern (AAIPI, 2014).

Menurut Standar Audit Intern Pemerintah Indonesia (AAIPI, 2014) auditor harus merencanakan dan melaksanakan pekerjaannya dengan menggunakan kemahiran profesionalnya secara cermat dan seksama (due professional care) dan secara hati-hati (prudent). Penggunaan kecermatan profesional menekankan tanggung jawab setiap Auditor untuk memperhatikan Standar Audit serta mempertimbangkan penggunaan audit berbasis teknologi dan teknik analisis data lainnya.

Menurut Arens (2003) dalam Yusuf (2014) kompetensi adalah kualitas pribadi yang harus dimiliki oleh seorang auditor yang diperoleh melalui latar belakang pendidikan formal auditing dan akuntansi, pelatihan kerja yang cukup dalam profesi dan akan ditekuninya dan selalu mengikuti pendidikan-pendidikan profesi yang berkelanjutan.

Sementara di dalam Standar Audit Intern Pemerintah Indonesia (AAIPI: 2014) disebutkan bahwa kompetensi auditor adalah dimana seorang auditor 
harus mempunyai pendidikan, pengetahuan, keahlian dan keterampilan, pengalaman, serta kompetensi lain yang diperlukan untuk melaksanakan tanggung jawabnya.

Etika dapat didefiniskan sebagai serangkaian prinsip atau nilai moral yang dimiliki oleh setiap orang. Lestari (2012) mengemukakan bahwa etika sebagai seperangkat aturan atau norma atau pedoman yang mengatur perilaku manusia, baik yang harus dilakukan maupun yang harus ditinggalkan yang dianut oleh sekelompok atau segolongan manusia atau masyarakat atau profesi.

Menurut Halim (2008:29) salah satu faktor yang berpengaruh terhadap kualitas audit adalah ketaatan auditor terhadap kode etik, yang terefleksikan oleh sikap independensi, obyektivitas, integritas dan lain sebagainya.

\section{METODE PENELITIAN}

Jenis penelitian ini merupakan penelitian kausal (causal), Umar (2008) menyebutkan desain kausal berguna untuk menganalisis bagaimana suatu variabel mempengaruhi variabel lain. Peneliti menggunakan desain penelitian ini untuk memberikan bukti empiris dan menganalisis faktor-faktor yang dapat mempengaruhi kualitas audit seperti pengalaman kerja, profesionalisme, integritas dan independensi sebagai variabel dependen dengan etika auditor sebagai variabel moderasi pada BPKP Provinsi Riau.

Populasi pada penelitian ini adalah seluruh auditor yang bekerja di BPKP Provinsi Riau yaitu berjumlah 91 orang (BPKP: 2019). Metode pengambilan sampel menggunakan metode purposive sampling. Tujuan penelitian adalah untuk mengetahui halhal yang dapat mempengaruhi kualitas audit, sehingga pengambilan sampel yaitu seluruh auditor yang sudah berpengalaman dianggap sesuai dengan tujuan penelitian ini. Metode pengumpulan data dengan menggunakan kuesioner dengan jumlah responden yang mengisi kuesioner tersebut adalah 46 orang. Model yang digunakan dalam penelitian ini menggunakan model regresi linear berganda yang dijabarkan sebagai berikut:

$$
\mathbf{Y}=\boldsymbol{\beta}_{0}+\boldsymbol{\beta}_{1} \mathbf{X}_{1}+\boldsymbol{\beta}_{2} \mathbf{X}_{2}++\boldsymbol{\beta}_{3} \mathbf{X}_{3}+\mathbf{e},
$$

dimana:

$\begin{array}{ll}\mathrm{Y} & : \text { Kualitas Audit } \\ \mathrm{X}_{1} & : \text { Kecermatan Profesional } \\ & \text { Auditor } \\ \mathrm{X}_{2} & : \text { Kompetensi Auditor } \\ \mathrm{X}_{3} & : \text { Etika Auditor } \\ \beta_{1} \ldots \beta_{3} & : \text { Koefisien variabel } \\ \mathrm{e} & : \text { Error term }\end{array}$

HASIL DAN PEMBAHASAN

Hasil Uji Regresi Linear Berganda

Hasil uji regresi linear berganda dapat dilihat pada Tabel 1 di bawah ini:

Tabel 1. Hasil Uji Regresi Linear Berganda

\begin{tabular}{llccc}
\hline \multirow{2}{*}{ Model } & \multicolumn{2}{c}{$\begin{array}{c}\text { Unstandardized } \\
\text { Coefficients }\end{array}$} & $\begin{array}{c}\text { Standardize } \\
\mathrm{d} \\
\text { Coefficients }\end{array}$ \\
\cline { 2 - 5 } & B & Std. Error & Beta \\
\cline { 2 - 5 } & $\begin{array}{l}\text { (Constant) } \\
\text { Kecermatan_Prof }\end{array}$ & .1393 & .567 & .139 \\
$\begin{array}{l}\text { esional } \\
\begin{array}{l}\text { Kompetensi } \\
\text { Auditor }\end{array}\end{array}$ & .371 & .162 & .327 \\
\hline Etika Auditor & .282 & .112 & .392 \\
\hline
\end{tabular}

a. Dependent Variable: Kualitas_Audit

Sumber: Hasil Olahan Data (2019)

Berdasarkan nilai koefisien yang terdapat pada tabel di atas maka dapat dibuat rumus regresi sebagai berikut:

$$
Y=1,393+0,133 X_{1}+0,371 X_{2}+0,282 X_{3}
$$


Adapun penjelasan dari persamaan regresi tersebut adalah sebagai berikut:

1. Konstanta bernilai positif sebesar 1,393 artinya jika variabel Kecermatan Profesional, Kompetensi Auditor dan Etika Auditor adalah konstan, maka Kualitas Audit sudah terbentuk sebesar 1,393.

2. Koesifien regresi pengaruh Kecermatan Profesional terhadap Kualitas audit adalah positif sebesar 0,133. Artinya, apabila Kecermatan Profesional ditingkatkan 100\% maka akan meningkatkan Kualitas Audit sebesar 0,133.

3. Koesifien regresi pengaruh Kompetensi Auditor terhadap Kualitas audit adalah positif sebesar 0,371. Artinya, apabila Kompetensi Auditor ditingkatkan 100\% maka akan meningkatkan Kualitas Audit sebesar 0,371.

4. Koesifien regresi pengaruh Etika Auditor terhadap Kualitas audit adalah positif sebesar 0,282. Artinya, apabila Etika Auditor ditingkatkan $100 \%$ maka akan meningkatkan Kualitas Audit sebesar 0,282.

\section{Koefisien Determinasi}

Koefisien Determinasi $\left(\mathrm{R}^{2}\right)$ digunakan untuk mengetahui seberapa besar variabel independen dapat menjelaskan variabel dependen. Hasil uji Koefisien Determinasi $\left(\mathrm{R}^{2}\right)$ dapat diketahui bahwa nilai koefisien $\left(\mathrm{R}^{2}\right)$ adalah sebesar 0,528 dengan nilai koefisien determinasi (Adjusted $R$ Square) adalah sebesar 0,482 atau $48,2 \%$. Hal ini berarti variabel independen yaitu Kecermatan Profesional, Kompetensi Auditor,dan Etika Auditor dapat menjelaskan Kualitas Audit sebesar 48,2\% sedangkan sisanya yaitu $51,8 \%$ dijelaskan oleh variabel lain diluar model ini.

\section{Hasil Uji t}

Dengan melihat pada tabel maka diperoleh nilai $t_{\text {tabel }}$ adalah 2,020. Kemudian nilai ini akan dibandingkan dengan nilai thitung. Hasil uji $\mathrm{t}$ pada penelitian ini dapat dilihat pada Tabel 2 di bawah ini:

Tabel 2 Hasil Uji t

\begin{tabular}{ccccc}
\hline Variabel & $\mathrm{t}$ tabel & $\mathrm{t}$ hitung & Sig. & Hasil \\
\hline $\begin{array}{c}\text { Kecermatan } \\
\text { Profesional } \\
\left(\mathrm{X}_{1}\right)\end{array}$ & 2,020 & 0,959 & 0,018 & $\begin{array}{c}\text { Tidak } \\
\text { berpengaruh } \\
\text { signifikan }\end{array}$ \\
\hline $\begin{array}{c}\text { Kompetensi } \\
\text { Auditor } \\
\left(\mathrm{X}_{2}\right)\end{array}$ & 2,020 & 2,292 & 0,027 & $\begin{array}{c}\text { Berpengaruh } \\
\text { signifikan }\end{array}$ \\
$\begin{array}{l}\text { Etika Auditor } \\
\left(\mathrm{X}_{3}\right)\end{array}$ & 2,020 & 2,517 & 0,016 & $\begin{array}{c}\text { Berpengaruh } \\
\text { signifikan }\end{array}$ \\
\hline $\begin{array}{l}\text { Sumber: Hasil Olahan Data }(2019) \\
\end{array}$
\end{tabular}

Hasil temuan dari penelitian yang dilakukan di Kantor BPKP Perwakilan Provinsi Riau, dan Kuesioner yang diperoleh maka dapat disimpulkan sebagai berikut :

1. Kecermatan Profesional tidak berpengaruh signifikan terhadap Kualitas Audit di BPKP Perwakilan Provinsi Riau dimana semakin rendah kecermatan professional maka semakin rendah pula kualitas audit yang dihasilkan. Menurut Standar Audit Intern Pemerintah Indonesia (AAIPI, 2014) auditor harus merencanakan dan melaksanakan pekerjaannya dengan menggunakan kemahiran profesionalnya secara cermat dan seksama (due professional care) dan secara hati-hati (prudent). Penggunaan kecermatan profesional menekankan tanggung jawab setiap Auditor untuk memperhatikan Standar Audit serta mempertimbangkan penggunaan audit berbasis teknologi dan teknik analisis data lainnya. 
2. Kompetensi Auditor berpengaruh signifikan terhadap Kualitas Audit di BPKP Perwakilan Provinsi Riau dimana semakin tinggi kompetensi auditor maka semakin baik kualitas audit yang dihasilkan. Di dalam Standar Audit Intern Pemerintah Indonesia (AAIPI: 2014) disebutkan bahwa kompetensi auditor adalah dimana seorang auditor harus mempunyai pendidikan, pengetahuan, keahlian dan keterampilan, pengalaman, serta kompetensi lain yang diperlukan untuk melaksanakan tanggung jawabnya.

3. Etika Auditor berpengaruh signifikan terhadap Kualitas Audit di BPKP Perwakilan Provinsi Riau dimana semakin tinggi etika auditor maka semakin tinggi pula kulitas audir yang di hasilkan. Lestari (2012) mengemukakan bahwa etika sebagai seperangkat aturan atau norma atau pedoman yang mengatur perilaku manusia, baik yang harus dilakukan maupun yang harus ditinggalkan yang dianut oleh sekelompok atau segolongan manusia atau masyarakat atau profesi.

\section{PENUTUP}

Kesimpulan

Berdasarkan hasil temuan dari penelitian yang dilakukan di Kantor BPKP Perwakilan Provinsi Riau, dan Kuesioner yang diperoleh maka dapat disimpulkan sebagai berikut (1)Kecermatan Profesional tidak berpengaruh signifikan terhadap Kualitas Audit di BPKP Perwakilan Provinsi Riau dimana semakin rendah kecermatan professional maka semakin rendah pula kualitas audit yang dihasilkan. (2) Kompetensi Auditor berpengaruh signifikan terhadap Kualitas Audit di BPKP Perwakilan Provinsi Riau dimana semakin tinggi kompetensi auditor maka semakin baik kualitas audit yang dihasilkan. (3)Etika Auditor berpengaruh signifikan terhadap Kualitas Audit di BPKP Perwakilan Provinsi Riau dimana semakin tinggi etika auditor maka semakin tinggi pula kulitas audir yang di hasilkan

\section{Saran}

Berdasarkan hasil penelitian yang diperoleh maka dapat disarankan untuk perbaikan sebagai berikut (1) Disarankan kepada auditor yang bertugas di BPKP Perwakilan Provinsi Riau agar memperkuat kecermatan professional yang seharusnya melekat pada diri auditor. (2) Diharapkan dengan adanya penelitian ini dapat digunakan sebagai bahan informasi dan bahan pengembangan bagi penelitian selanjutnya dengan menambah variable penelitian yang lain sehingga mendapatkan penelitian yang lebih baik

\section{UCAPAN TERIMAKASIH}

Terima kasih banyak ditujukan kepada pihak Direktorat Riset dan Pengabdian Masyarakat Direktorat Jenderal Penguatan Riset dan Pengembangan, Kementerian Riset, Teknologi, dan Pendidikan Tinggi yang telah menyediakan dana untuk penyelesaian penelitian ini Sesuai Kontrak Penelitian Tahun Anggaran 2019 Nomor SP DIPA-042.06.1.401516/2019, tanggal 5 Desember 2018

\section{DAFTAR PUSTAKA}

Agusti, R \& Nastia, P.,P. (2013). Pengaruh Kompetensi, Independensi dan Profesionalisme terhadap Kualitas Audit (Studi Empiris pada Kantor Akuntan Publik Sumatera). Jurnal Ekonomi, 21(3)

Al-Khaddash, Husam, Al-Nawas, Rana \& Ramadan, A. (2013). Factors Affecting the Quality of Auditing: 
The Case of Jordanian Commercial Banks. International Journal of Business and Social Science, 4(11)

Badan Pemeriksa Keuangan. (2008). Panduan Manajemen Pemeriksaan Tahun 2008. BPK RI. Jakarta.

Badjuri, A. (2011). Faktor-Faktor yang Berpengaruh Terhadap Kualitas Hasil Pemeriksaan Auditor Sektor Publik. Prosiding Seminar Nasional Multi Disiplin Ilmu \& Call For Papers Unisbank (Sendi_U).

Bouhawia, Mohammed S., Irianto, Agus \& Baridwan, Z. (2015). The Effect of Working Experience, Integrity, Competence, and Organizational Commitment on Audit Quality (Survey State Owned Companies in Libya). IOSR Journal of Economics and Finance (IOSR-JEF) 6(4), 60-67.

Butt, J.L. (1988). Frequency Judgment in an Auditing related task. Journal of Accounting Research, 26 (Autumn), page. 315-30.

De Angelo, L.E. (1981). Auditor Independence, "Low Balling", and Disclosure Regulation. Journal of Accounting and Economics 3. Agustus. p. 113127.

Dewi, Dewa, A.,C \& Budiartha, I.K. Pengaruh Kompetensi dan Independensi Auditor pada Kualitas Audit Dimoderasi oleh Tekanan Klien. E-Jurnal Akuntansi Universitas Udayana.11(1), 197-210.

Febriansyah, Erwin, Rasuli, M \& Hardi. (2014). Pengaruh Kehalian, Independensi, Kecermatan Profesional, Dengan Etika Sebagai Variabel Moderasi Terhadap Kualias Auditor pada
Inspektorat Provinsi Bengkulu. Jurnal Sorot, 8(1), 1-104.

Futri, P.,S \& Juliarsa, G. (2014). Pengaruh Independensi, Profesionalisme, Tingkat Pendidikan, Etika Profesi, Pengalaman dan Kepuasan Kerja Auditor pada Kualitas Audit Kantor Akuntan Publik di Bali. EJurnal Akuntansi Universitas Udayana, 7(2), 444-461.

Halim, A. (2008). Auditing. Yogyakarta: Sekolah Tinggi Ilmu Manajemen YKPN.

Halim, A \& Muhammad, S.,K .(2012). Akuntansi Sektor Publik. Salemba Empat. Jakarta.

Jeffrey, C \& Nancy, W. (1996). Ethical Development, Profesional, Commitment, and Rule Observance Attitudes : A Study of CPA'S and Corporate Accountants. Behavioral Research in Accounting, 8(1), 829.

Jelic, M. (2012). The Impact of Ethics on Quality Audit Results. International Journal for Quality research. 6(4), 333-342.

Kharunnisa, S., Nor, W \& Octaviani, A. (2015). Pengaruh Kompetensi dan Independensi terhadap Kualitas Audit: Etika Auditor Sebagai Variabel Pemoderasi (Studi Empiris pada BPKP Perwakilan Kalimantan

Selatan).www.multipradigma.lect ure. ub.ac.id.

Lubis, A.,A. (2015). Pengaruh Pengalaman Kerja, Independensi, Objektivitas, Integritas, Kompetensi dan Etika Auditor Terhadap Kualitas Hasil Pemeriksaan Auditor BPKP Provinsi Sumatera Utara. Tesis Sekolah Pascasarjana Universitas Sumatera Utara. 
http://repository.usu.ac.id/xmlui/h andle/123456789/47761

Lindawati. (2013). Pengaruh Kecermatan Profesional dan Pengalaman Kerja Terhadap kualitas Hasil Pemeriksaan.

Marsellia, M, Carmel \& Hermawan, B. (2017) Pengaruh Kompetensi dan Independensi Terhadap Kualitas Audit Dengan Etika Auditor Sebagai Variabel Moderator (Studi Empiris Pada Auditor di KAP Big Four Jakarta). Jurnal online unisbank. http://eprints.unisbank.ac.id/ 178/1/artikel-16.pdf

Mufidah. (2015). Analisis Pengaruh Independensi, Obeyektifitas, Integritas, Kompetensi, Pengalaman Kerja dan Skeptisisme Profesional terhadap Kualitas Hasil Pemeriksaan di Lingkungan Inspektorat Provinsi Jambi. Jurnal Akuntansi dan Keuangan Universitas Jambi 2(2).http://onlinejournal.unja.ac.id/index.php/jaku/ article/view/2518.

Mulyadi. (2013). Auditing. Salemba Empat. Jakarta.

Peraturan Menteri Negara Pendagunaan Aparatur Negara Nomor: PER/4/M.PAN/03/2008 tentang Kode Etik APIP.

Priyambodo, D. (2015). Pengaruh Kompetensi, Independensi, Pengalaman Kerja, dan Akuntabilitas Terhadap Kualitas Audit Dengan Etika Auditor Sebagai Variabel Moderating (Studi Empiris Pada Kantor Akuntan Publik di Surakarta dan Yogyakarta). http://eprints.ums.ac.id/36609/14
/Naskah\%20Publikasi.pdf

Pusdiklatwas BPKP.2009. Auditor Ahli dan Auditor Terampil. BPKP RI. Jakarta.

Samsi, N, Riduan, A \& Suryono, B. (2013). Pengaruh Pengalaman Kerja, Independensi, dan Kompetensi Terhadap Kualitas Hasil Audit: Etika Auditor Sebagai Variabel Moderasi. Jurnal Ilmu dan Riset Akuntansi, 1(2)

Simatupang, P.,Y. (2012). Pengaruh Tingkat Pendidikan, Pengetahuan, Kecakapan Profesional, Pendidikan Berkelanjutan, Independensi, Kepatuhan Kepada Kode Etik Terhadap Kualitas Hasil Pemeriksaan Laporan Keuangan dengan Pengalaman Kerja Sebagai Variabel Moderating.http://ejournal.uajy.ac.id/969/2/1EA1634 1.pdf.

Sutton, S.,G. (1993). Toward an Understanding of The Factors Affecting the Quality of The Audit Process. Decission Sciences, 24(2),88 -105.

Tita, S, Dandes, R \& Herawati. (2012). Pengaruh Independensi, Integritas, dan Profesionalisme Auditor Terhadap Kualitas HasilPemeriksaan. Universitas Bung Hatta.

Umar, H. (2008). Metode Riset Akuntansi Terapan. Cetakan Pertama. Ghalia Indonesia. Jakarta. 